\title{
REVISÕES
}

\section{Tumorogênese em plantas causadas por espécies de Agrobacterium}

\author{
Reginaldo da Silva Romeiro, José Roberto Vieira Júnior e Sérgio Hermínio Brommonschenkel
}

Universidade Federal de Viçosa. Departamento de Fitopatologia. CEP 36.570-000, Viçosa, MG, Brasil.

Data de chegada: 28/12/2004. Aceito para publicação em: 28/12/2005.

\section{RESUMO}

Romeiro, R.S.;Vieira Júnior, J.R.;Brommonschenkel S.H. Tumorogênese em plantas causadas por espécies de Agrobacterium. Summa Phytopathologica, v.33, n.1, p.9-15, 2007.

Tumores - sintomas hiperplásicos em plantas - incitados por espécies de Agrobacterium sp. sempre exerceram fascínio sobre fitopatologistas desde o início do Século XX, quando Erwin Smith e colaboradores demonstraram serem eles de etiologia bacteriana. No início, imaginava-se que os tumores eram decorrentes de alterações hormonais na planta provocadas pela bactéria. Contudo, até recentemente, a microbiologia e a biologia molecular não eram suficientemente avançadas para que os cientistas pudessem compreender e deduzir a forma através da qual o patógeno incitava os tumores. Demorou quase um século para que se deslindassem os complexos mecanismos bioquímicos, genéticos e fi-siológicos através dos quais o patógeno transforma a planta, inserindo no genoma desta uma região de seu megaplasmídeo de modo a criar para si mesmo um nicho ecológico espe-cífico. Neste trabalho é apresentada uma súmula histórica da evolução do conhecimento a respeito, das características genômicas do plasmídeo Ti, dos eventos e requerimentos ati-nentes ao processo infectivo bem como é discutida a dinâmica da transformação da planta pelo patógeno.

Palavras-chave adicionais: Tumores, Bactérias fitopatogênicas, Oncogenia, Transformação, Plasmídio Ti

\begin{abstract}
Romeiro, R.S.;Vieira Júnior, J.R.;Brommonschenkel S.H. Tumorigenesis in plants induced by species of Agrobacterium. Summa Phytopathologica, v.33, n.1, p.9-15, 2007.

Tumors - the plant hyperplasia symptoms- - induced by species of Agrobacterium sp. have deeply impressed plant pathologists since early $20^{\text {th }}$ Century when Erwin Smith and his co-workers demonstrated that such tumors had a bacterial etiology. Nevertheless, until recently the state of art of Microbiology and Molecular Biology was not developed enough for scientists to realize and to elucidate the complexes biochemical, genetic and physiologic mechanisms by which

the pathogen transforms the plant by inserting a region of its own plasmid into the genome of the latter, creating an specific ecological niche for itself. In this paper its is showed a historical brief on the evolution of knowledge about the genomic characteristics of the $\mathrm{Ti}$ Plasmid, events and requirements needed for infection to take place as well as it is discussed the transformation dynamics of the host by the pathogen.

Additional keywords: Tumors, Phytobacteria, Oncogeny, Transformation, Ti plasmid
\end{abstract}

Agrobacterium tumefaciens é um patógeno de solo que causa tumores em uma ampla gama de espécies de plantas hospedeiras $(1 ; 17 ; 45)$, os quais são uma conseqüência da multiplicação autônoma e desordenada de células no sítio de infecção (23). Algumas décadas atrás, acreditava-se que $A$. tumefaciens, ao infectar plantas, promovia algum tipo de desequilíbrio hormonal que ocasionava um crescimento desordenado de células no sítio de infecção, ocasionando então a formação do tumor. Contudo, o estado de arte da Microbiologia e da Biologia Molecular ainda não era suficientemente avançado para que os cientistas do passado pudessem compreender e deduzir a forma através da qual o patógeno incitava tumores.
Súmula histórica da evolução do conhecimento

Tumores em plantas, incitados por Agrobacterium sp., são conhecidos desde o início do século XX, quando Smith \& Townsend (37) descreveram, pela primeira vez, a galha em coroa como sendo incitada por uma bactéria, na época denominada Bacillus tumefaciens. Com a descoberta das auxinas, Link \& Eggers (26) mostraram que tumores em tomateiro produziam quantidades anormais desse hormônio. No mesmo ano, White \& Braun (42) observaram que células de tumor eram capazes de se multiplicar, em cultura, na ausência da bactéria e de outros fatores de crescimento geralmente necessários, o que levou Braun (3), já naquela época, hipotetizar que essas células originárias de tumores haviam sofrido algum tipo de transformação. 
Assim, Braun hipotetizou que Agrobacterium seria a fonte de um "princípio de indução de tumor" (tumor inducing principle), talvez DNA, que transformava células da planta embora não houvesse chegado a comprovar isso $(3 ; 5)$. Na década de 50 , citocininas foram reconhecidas como reguladoras de crescimento vegetal e, em seguida, Braun (4) passou a acreditar no seu envolvimento com os tumores incitados por Agrobacterium.

Talvez a primeira evidência a respeito da natureza genética e, ou, bioquímica do "princípio de indução de tumor" tenha vindo do trabalho de Georges Morel e sua equipe, no INRA (Institut National de la Recherche Agronomique, Versalhes, França), no correr da década de 60, conforme relata Chilton (8). Segundo Petit et al (32), no INRA, descobriu-se que os tumores, mesmo livres de bactérias, continham altos níveis de opinas. Constatou-se também que havia isolados bacterianos que sintetizavam octopinas e outros nopalinas e, isolados que sintetizavam e utilizavam uma dada octopina, induziam a formação de tumores que também sintetizavam esta octopina. Assim, a informação para a síntese da opina parecia passar da bactéria para a planta e poderia ser alguma forma móvel de DNA como Braun (3) havia afirmado muitos anos antes.

Durante as décadas de 60 e 70, duas descobertas trouxeram mais luz para a elucidação do fenômeno. O primeiro foi a de Allen Kerr, da Universidade de Adelaide (Austrália) - a capacidade de causar tumores podia ser passada de um isolamento bacteriano virulento para outro avirulento (21). Embora o mecanismo de transferência fosse desconhecido, isso era uma sólida evidência de mobilidade de algo transferível, um transposon ou um plasmídeo, talvez, que continha a informação para a síntese da opina, talvez o "princípio de indução de tumor" (Figura 1). Adicionalmente, segundo Chilton (8), um grupo de pesquisa da Universidade de Ghent (Bélgica), liderado por Jeff Schell e Marc van Montagu, em 1974, encontraram megaplasmídeos em isolamentos virulentos do patógeno mas não nos avirulentos. Parecia, a este ponto, haver boas evidências de que o "princípio de indução de tumor" era algum tipo de informação genética contida neste megaplasmídeo, daí seu nome atual de plasmídeo Ti.

Só isolados possuindo esse plasmídeo grande induziam tumores e catabolizavam opinas (1). Contudo, faltava ainda mais um passo, crucial esse - era preciso encontrar vestígios de fragmentos do

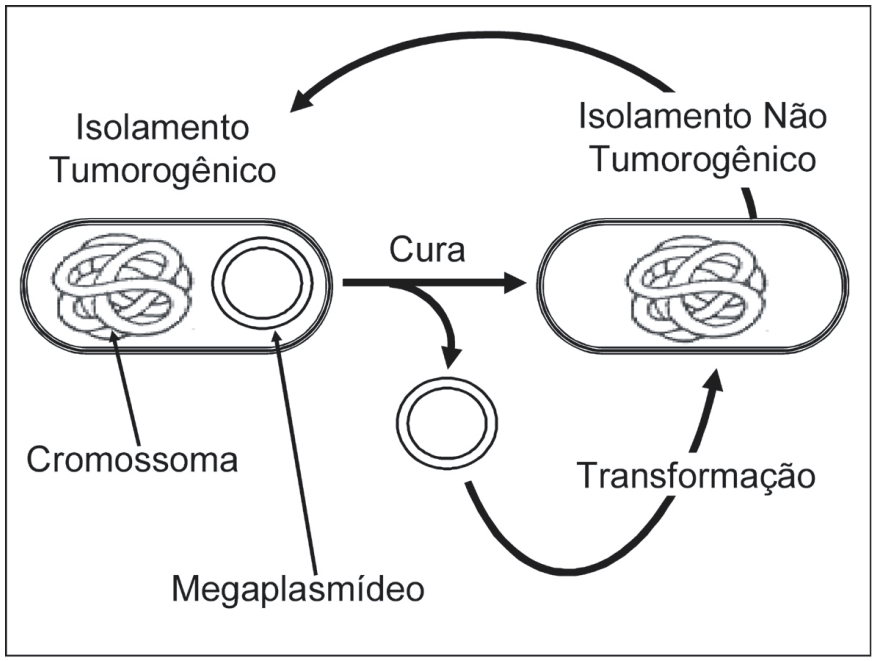

Figura 1. Flutuações em virulência de isolamentos de Agrobacterium tumefaciens, em função em cura, inserção e re-inserção do megaplasmídeo, conforme resultados de Kerr (1969) e de Van Larebeke et al (1975). megaplasmídeo em associação com o genoma da planta. Segundo relato da própria pesquisadora como de outros cientistas $(1 ; 8 ; 9 ; 13 ; 45)$ o mérito de haver provado estar uma parte do megaplasmídeo Ti associado ao genoma de células tumorais cabe a Mary Dell Chilton. Trabalhando na Universidade de Washington, Seattle, USA, juntamente com outros pesquisadores como Eugene W. Nester, Milton P. Gordon e estudantes de pós-graduação, foi realizado o trabalho básico e pioneiro (10).

De maneira muito simplificada, no experimento de Chilton et al (10), plantas de fumo foram inoculadas com um isolamento virulento de A. tumefaciens e aguardou-se o desenvolvimento de tumores. Paralelamente, o Plasmídeo Ti foi isolado (Figura 2), fracionado em 20 fragmentos de tamanhos diferentes (Figura 3) pelo uso de uma endonuclease de restrição (Sma I) e essa mistura de fragmentos separada por eletroforese e sonda radioativas foram preparadas, a partir de fragmentos.

Adicionalmente, o DNA total foi isolado de células de tumores livres da bactéria, fracionado enzimaticamente, originando uma mistura de milhões de fragmentos. Essa mistura foi separada por eletroforese

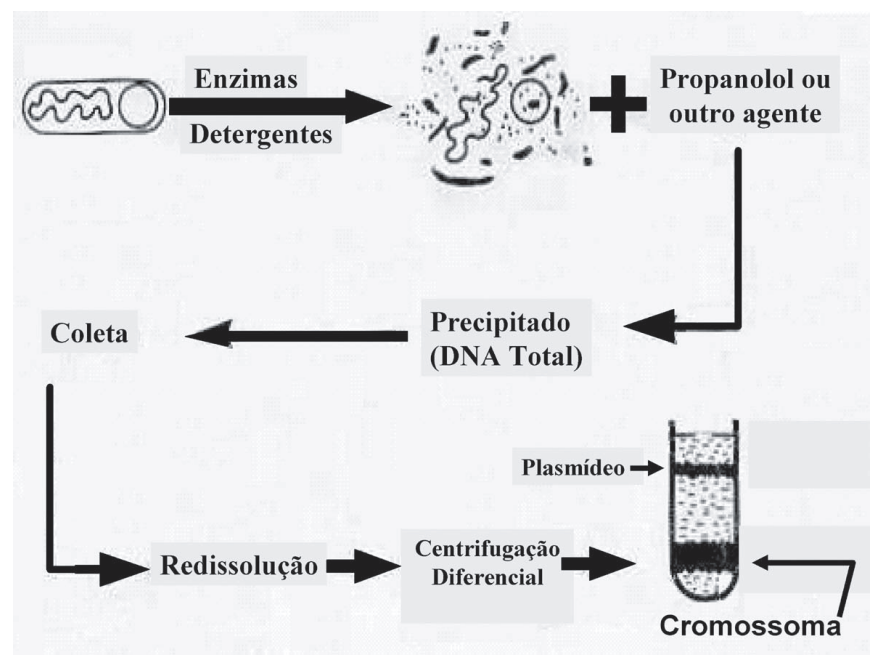

Figura 2. Esquema de um dos procedimentos utilizados para isolamento da fração plasmidial bacteriana.

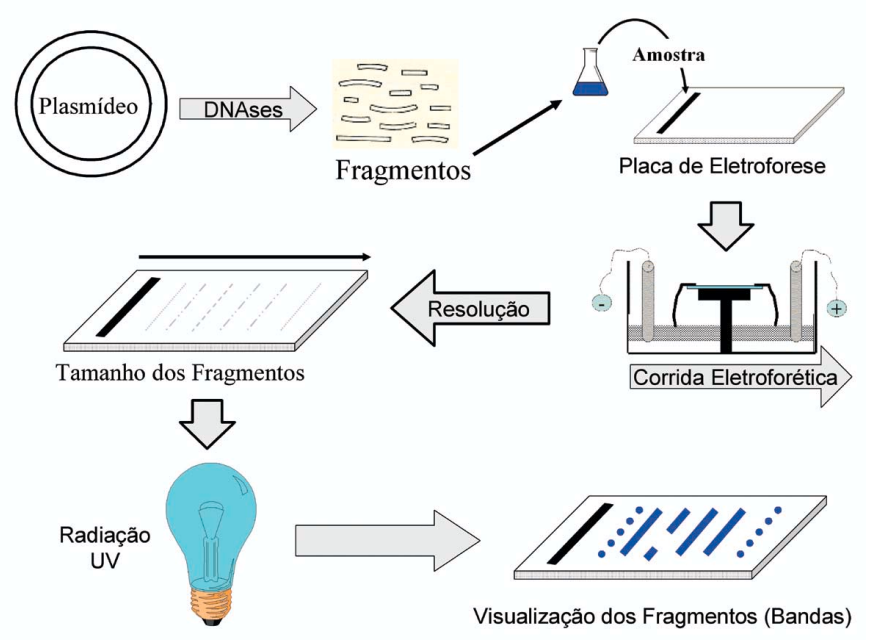

Figura 3. Digestão enzimática e resolução da mistura de fragmentos de um plasmídeo, por eletroforese. 
e transferida para um filtro pela técnica conhecida como "Southern Dot Blot" (11; 14; 29). Quando esse filtro foi hibridizado com fragmentos do plasmídeo marcado detectou-se, no produto da corrida eletroforética, fragmentos de DNA pertencentes ao plasmídeo e que estavam inseridos e associados ao genoma da planta transformada (Figura 4). Estava provado que uma porção do Plasmídeo Ti (contendo genes para tumorogênese, síntese e catabolismo de opinas), hoje denominada T-DNA, era transferida para a célula da planta, incorporando-se ao seu genoma e transformando-a.
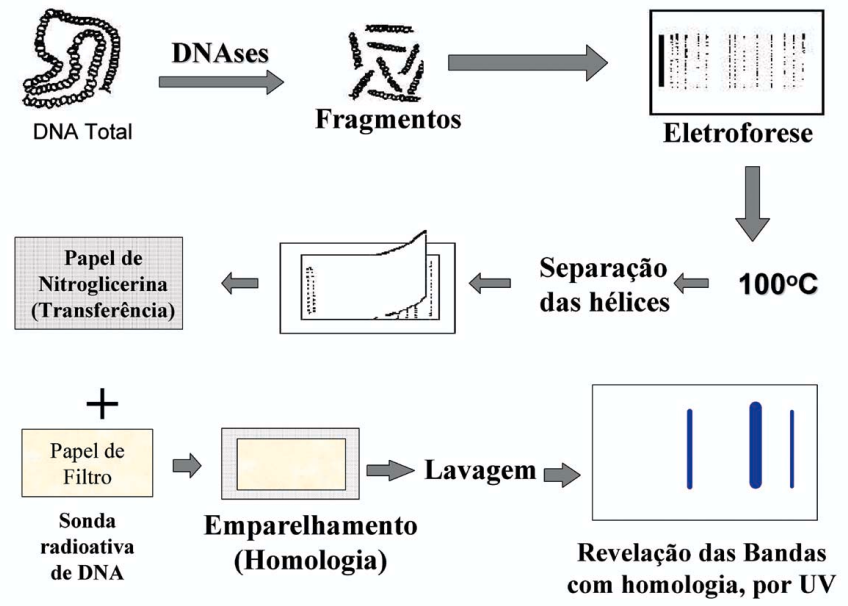

Figura 4. Técnica de "southern dot blot" utilizada por Chilton et al (1977) para detectar a presença de fragmentos do Plasmídeo Ti inserido e incorporado ao núcleo de células de tumor incitado por Agrobacterium tumefaciens.

O Plasmídeo Ti e suas características genômicas

O plasmídeo Ti contém cerca de 200 quilobases, existindo em cópia única, com genes que codificam para múltiplas funções, quase todas relacionadas com a transferência e integração deste plasmídeo (o T-DNA) no genoma da célula vegetal. Na Figura 5 está esquematizado o mapa genômico simplificado do plasmídeo Ti, em que os agrupamentos gênicos mais importantes estão assinalados e nomeados. Sobre esses agrupamentos, é de monta comentar:

a) Região T-DNA (ou DNA de transferência) - contém a porção de DNA que será transferida, na forma de um fio único. Tem suas extremidades (esquerda e direita) delimita-das por 25 pares de bases em repetições diretas imperfeitas. Qualquer sequiência de bases que

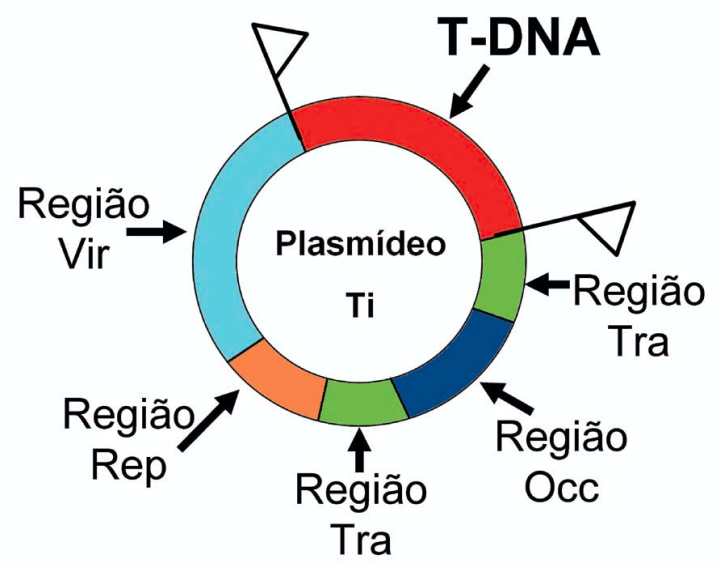

Figura 5. Mapa genômico do Plasmídeo Ti, em que as regiões mais importantes são assinaladas. for inserida entre essas duas extremidades, será integralmente transferida para a planta, independente de seu tamanho, e inserida, ao acaso, ao seu genoma.

b) Genes Vir ou Região Vir (Vir = virulência) - Genes desse agrupamento codificam para, respectivamente: expressão de produtos responsáveis pelo processo de exportação do T-DNA da bactéria para a planta; catabolismo de opinas; transferência conjugacional do plasmídeo Ti para outros isolados de Agrobacterium sp. Na Região Vir estão os agrupamentos A, B, C, D, E, F e G, que contêm os genes $\operatorname{Vir} A, \operatorname{Vir} B, \operatorname{Vir} C, \operatorname{Vir} D, \operatorname{Vir} E$, VirF e $\operatorname{Vir} G$, todos participantes ativos do processo geral de transformação da planta pelo patógeno.

c) Região Occ - Nesse grupamento estão os genes que codificam para síntese e catabolismo de opinas.

d) Região Rep - Aqui estão os genes responsáveis pela autoreplicação do plasmídeo (29; 38).

e) Região Tra - A expressão de genes situados nessas duas regiões origina produtos que governam a transferência conjugacional do plasmídeo Ti para outras espécies compatíveis de Agrobacterium.

\section{O processo infectivo - eventos e requerimentos}

O ponto crítico para a bactéria conseguir infectar a planta é estarem as células dessa última "competentes" ou em "estado de competência" para receber o fragmento de genoma a ser inserido (2). Há muito se sabe que ferimentos são essenciais para que a infecção aconteça (23; 39), não só por serem portas de entrada como também por alterarem a fisiologia do tecido no local e facilitar o contato entre as células do patógeno e do hospedeiro, por exporem sítios receptores (Figura 6) nas últimas $(27 ; 34)$.

Parece que a bactéria infectante é capaz de perceber alterações no ambiente, decorrentes dos ferimentos nos hospedeiros $(7 ; 16)$. Li et al (25), supõem que uma proteína sensora, ChvG, localizada no cromossoma e não no plasmídeo Ti, é importante na virulência de $A$. tumefaciens pois ela permite à bactéria monitorar aumento de acidez resultante do ferimento e isso é um passo necessário para a transferência do plasmídeo Ti

Quando o ferimento ocorre, células do hospedeiro circunvizinhas do local iniciam uma resposta inespecífica de defesa que inclui a síntese de compostos fenólicos $(6 ; 15 ; 18 ; 24 ; 31)$, de açúcares envolvidos na síntese da parede celular $(31 ; 36 ; 43)$ e há liberação de íons $\mathrm{H}^{+}$nos espaços intercelulares (25), o que culmina com o abaixamento do $\mathrm{pH}$ no local do ferimento. Fenóis, juntamente com os açúcares e os íons

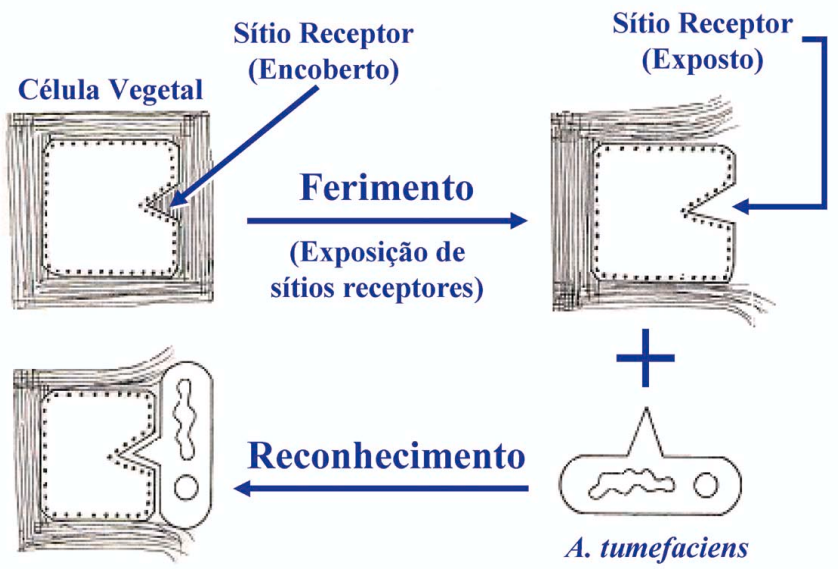

Figura 6. Ferimentos e exposição de sítios receptores para Agrobacterium tumefaciens na parede celular da planta hospedeira. Adaptado de Romeiro (1985). 
$\mathrm{H}^{+}$são reconhecidos bioquimicamente pela bactéria infectante e servem para desencadear os fenômenos seguintes.

Outro evento importante é a tentativa de reparo realizada pela planta. Assim que o ferimento ocorre, células da planta sofrem alguns ciclos de divisão com este fim, como se fosse uma tentativa imediata e biológica de cicatrização. Embora ainda não esteja muito claro de que forma, parece que essa divisão celular, de algum modo, aumenta a eficiência com que oT-DNA é transferido.

A. tumefaciens precisa se ligar a sítios receptores específicos da célula vegetal, presentes em sua parede, ainda que a natureza e topologia desses sítios careçam de mais estudos $(2 ; 13 ; 41 ; 45)$. Algumas evidências experimentais parecem indicar que esses sítios receptores, talvez sejam constituídos de glicoproteinas $(7,16)$.

\section{Tumorogênese e vantagens específicas para o patógeno}

No plasmídeo Ti estão genes que codificam para a síntese e catabolização de opinas, que são complexos de carboidratos e aminoácidos (Figura 7). As opinas são divididas em dois grandes grupos - octopinas e nopalinas $(9 ; 22)$. Em verdade, opinas são conjugados de compostos comuns em plantas, mas ligados de forma incomum. Geralmente não são sintetizados por plantas nem por elas utilizados e, raramente, outros microrganismos que não espécies de Agrobacterium, são também capazes de utilizá-los.

O patógeno transforma a planta de uma forma inteligente ao criar, para si mesmo, uma vantagem seletiva ou um nicho ecológico com exclusividade, pois só ele é capaz de utilizar, como fonte de carbono (C) e nitrogênio (N), a opina cuja síntese é codificada por genes localizados no seu plasmídeo Ti e que, após a inserção do TDNA, passa também a ser sintetizada pela planta e colocada à sua disposição. Conforme de Zupan et al, (45), ao introduzir seu material genético na planta, a bactéria prepara uma "colonização genética" por criar um habitat único e específico ao qual somente ela está geneticamente equipada para utilizar a fonte de $\mathrm{C}$ e de $\mathrm{N}$ predominante (opina específica).

\section{Dinâmica da transformação da planta pelo patógeno}

Na Figura 8, está esquematizada uma sinopse da seqüência de eventos, para um melhor entendimento inicial. Para efeito didático e explicativo, o processo de transformação pode ser dividido em seis fases, como se segue.

Fase 1 -A bactéria penetra e necessita ligar-se a sítios receptores específicos na parede da célula vegetal (Figura 9). Detalhes sobre esses sítios ainda não são conhecidos mas há indicações de que esses receptores sejam de natureza glicoprotéica $(7 ; 16)$.

\begin{tabular}{|c|c|}
\hline $\mathrm{CHOH}-(\mathrm{CHOH})_{3}$ & $\begin{array}{c}\mathrm{CH}-\mathrm{NH}-\left(\mathrm{CH}_{2}\right)_{3}-\mathrm{CH}-\mathrm{COOH} \\
\mathrm{HOOC}-\left(\mathrm{CH}_{2}\right)_{2}-\mathrm{CH}-\mathrm{COOH}\end{array}$ \\
\hline $\begin{array}{cc}\mathrm{CH}_{2} \mathrm{OH}-(\mathrm{CHOH})_{4}-\mathrm{CH}_{2} & \mathrm{C} \\
\text { । } & \\
\mathrm{NH} & \\
\mathrm{HOOC}-\mathrm{CH}-\left(\mathrm{CH}_{2}\right)_{2}-\mathrm{C} & \mathrm{O} \\
\mathrm{NH}_{2} & \end{array}$ & $\begin{array}{c}\mathrm{H}_{2} \mathrm{~N}>\mathrm{C}-\mathrm{NH}-\left(\mathrm{CH}_{2}\right)_{3}-\mathrm{CH}-\mathrm{COOH} \\
\mathrm{IN} \\
\mathrm{NH} \\
\stackrel{\mathrm{CH}}{\mathrm{CH}}-\mathrm{COOH}\end{array}$ \\
\hline
\end{tabular}

Figura 7. Estrutura química de algumas opinas: $(\mathrm{A})=\operatorname{agropina} ;(\mathrm{B})=$ octopina; $(\mathrm{C})=$ manopina; $(\mathrm{D})=$ nopalina.

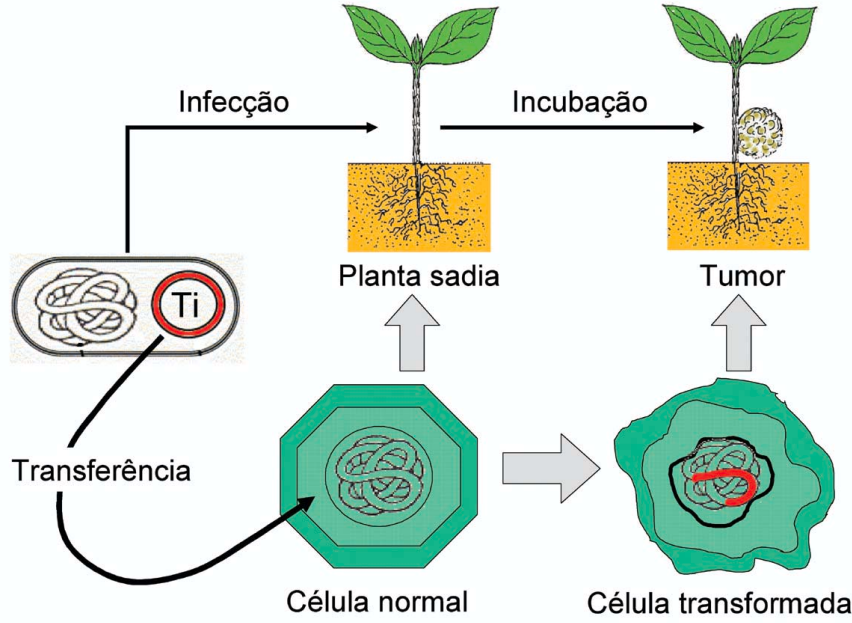

Figura 8. Sinopse do processo de tumorogênese em plantas, incitada por Agrobacterium tumefaciens.

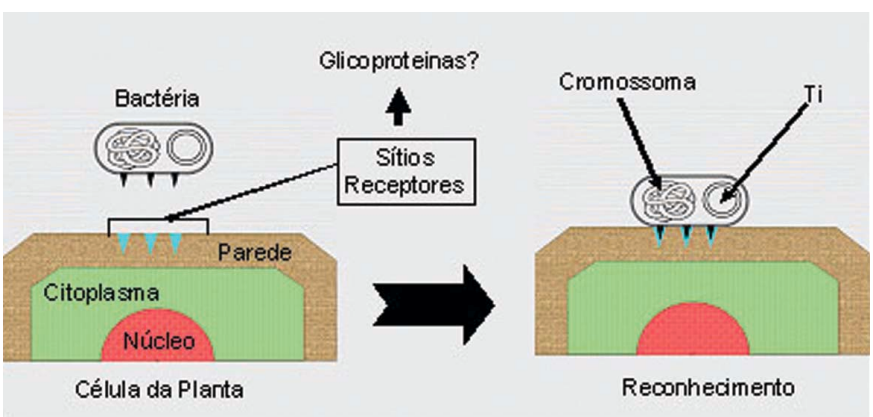

Figura 9. Fase 1, em que a bactéria, após os eventos iniciais de sinalização recíproca, acopla-se a sítios receptores (glicoproteinas, talvez) na superfície da célula da planta.

Fase 2 - Após a ligação da célula bacteriana a sítios receptores na parede da célula da planta, inicia-se e expressão dos genes Vir (Vir A e Vir G), localizados na região Vir do Plasmídeo Ti, devido à presença de moléculas liberadas pela planta no local do ferimento (fenóis, açúcares e também de prótons), conforme mostrado na Figura 10.

Células do hospedeiro são reconhecidas pelos produtos da expressão de $\operatorname{Vir} A$ e de $\operatorname{Vir} G$, o que resulta na expressão de outros genes. A expressão constitutiva de VirA e VirG é necessária. Vir A é uma quinase associada à membrana e $\operatorname{Vir} G$ é o regulador da resposta. Vir A é capaz de autofosforilação, passando a perceber as substâncias liberadas pelo ferimento e de transferir fosfato para VirG. Como decorrência da fosforilação de $\operatorname{Vir} G$, ele torna-se fator de transcrição, induzindo a expressão de muitos genes Vir, inclusive Vir A e Vir G. Segundo Binns \& Campbell (2), os fenóis e os prótons é que são requeridos para ativação dos genes Vir e não os açúcares mas a presença desses torna o sistema $\operatorname{VirA} / \operatorname{Vir} G$ cem vezes mais eficiente.

Fase 3 - Como resultado da expressão dos genes Vir, o T-DNA começa a ser preparado e processado, para a transferência. Os bordos dos 25 pares de bases das extremidades direita e esquerda do T-DNA são reconhecidos pelo complexo protéico $\operatorname{Vir} D_{I} / D_{2}$ que age como uma endonuclease e corta um segmento (monofio), chamado ssT-DNA. Este monofio liga-se, pelo terminal 5', à 


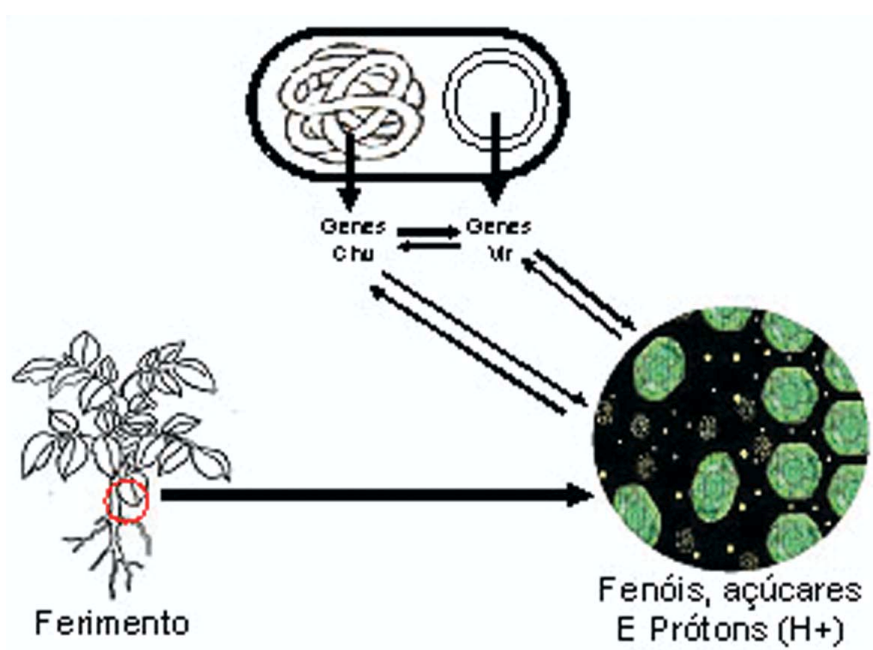

Figura 10. Genes no cromossomo e no Plasmídeo Ti e os produtos de sua expressão detectam alterações na composição da planta, no sítio do ferimento, principalmente açúcares, fenóis e acidificação, dando início à expressão dos genes Vir.

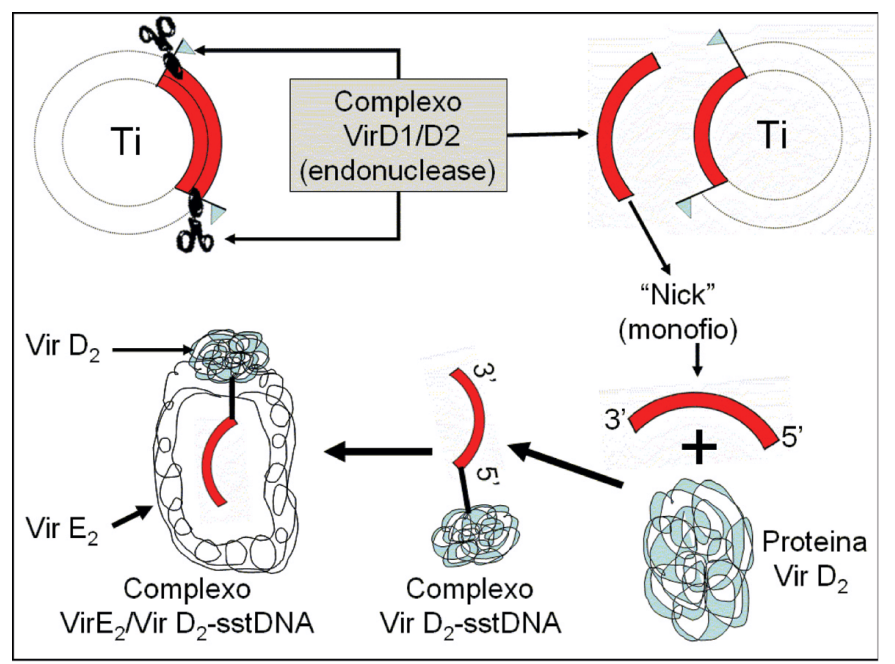

Figura 11. Seccionamento de um monofio doT-DNA pelo complexo VirD1/VirD2, sua ligação covalente com VirD2 (Complexo VirD2-ssTDNA) e associação do complexo a VirE2 que protege o monofio contra exonucleases.

proteína $\operatorname{Vir} E_{2}$ que, por sua vez, muda sua conformação de modo a envolver o monofio, protegendo-o contra nucleases. Na Figura 12 está esquematizado, em linhas gerais, o processo.

Fase 4 - O monofio de T-DNA, em associação com proteínas específicas, é exportado para fora da célula bacteriana e para dentro da célula da planta, graças à ação de várias proteínas Vir. Essas proteínas parecem formar uma estrutura semelhante a um poro $(20 ; 30 ; 45)$ entre a célula bacteriana e a célula da planta e este complexo protéico associado à membrana tem sido genericamente denominado Sistema Secretório Tipo IV $(12 ; 28 ; 33 ; 35 ; 44)$.

Existem evidências de que 11 proteínas VirB juntamente com $\operatorname{Vir} D 4$, formam um complexo associado à membrana, tubular, dando passagem a VirD2-ssT-DNA, VirE2 ou um complexo de ambos (19). Esse complexo ou poro, teria uma anatomia, em termos de estrutura, semelhante a um pilus (Figura 13), segundo Kado (19) e Veena et al, (40).

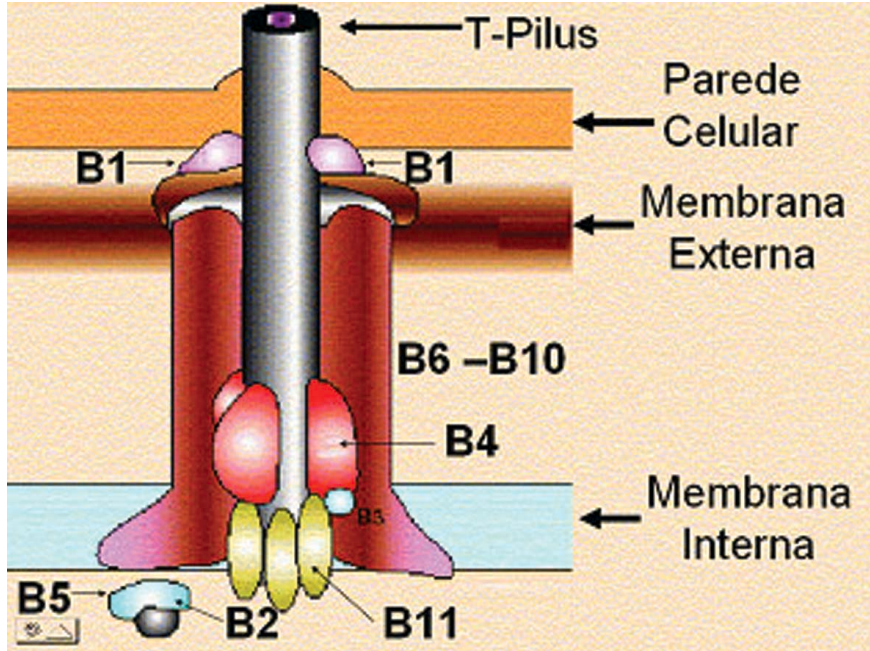

Figura 12. Presumida estrutura do poro, semelhante a um pilus, através do qual o ssT-DNA faz a passagem do citoplasma da célula bacteriana para o citoplasma da planta a ser transformada. Redesanhado a partir de Kado, (2000).

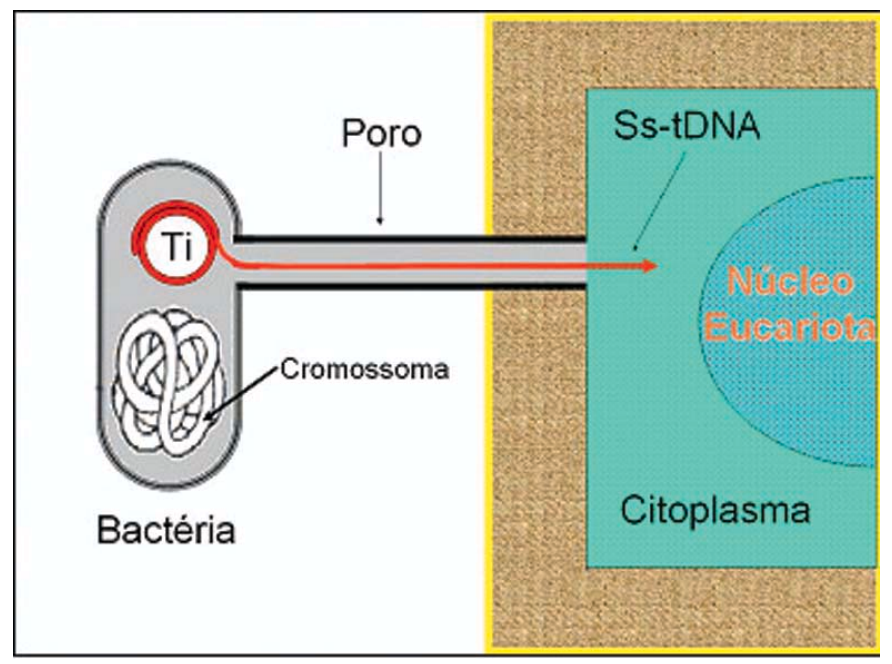

Figura 13. Formação de um poro, com estrutura semelhante à de um pilus, que funciona como uma seringa genômica, permitindo que o procariota (Agrobacterium tumefaciens) injete um fragmento de genoma no citoplasma do eucariota (planta hospedeira).

O poro, semelhante a um pilus, funcionaria como uma seringa molecular, transpassando a parede celular da bactéria, a parede celular da célula da planta e dispensando o fragmento de ssDNA diretamente no citoplasma eucariota (Figura 13).

Fase 5 - O ssT-DNA, ainda associado a proteínas, uma vez dentro da célula do hospedeiro, é direcionado para o núcleo, por ação de sinais bioquímicos presentes em VirD2 e VirE2, que interagem com mecanismos próprios de localização nuclear. Uma vez dentro do núcleo, o monofio se integra, de forma estável, ao genoma da planta. O local de inserção do T-DNA no genoma da planta parece ser ao acaso e mais de um T-DNA pode ser integrado.

Fase 6 - O T-DNA inserido no genoma da planta contém genes que codificam para a biosíntese de auxinas e de citocininas. O acumulo dessas substâncias nos tecidos que circundam o sítio de infecção estimula contínuas divisões celulares, originando o tumor. 


\section{REFERÊNCIAS BIBLIOGRAFICAS}

1.Binns, A. N. T-DNA of Agrobacterium tumefaciens: 25 years and counting. Trends in Plant Science, London, v.7, p.231-233, 2002

2.Binns, A. N.; Campbell, A. Agrobacterium tumefaciens-mediated transformation of plant cells. Encyclopedia of Life Sciences, London, v.1, p.1-6, 2001

3.Braun, A. C. Thermal studies on the factors responsible for tumor initiation in crown gall. American Journal of Botany, St. Louis, v.34, p.234-240, 1947

4.Braun, A. C. A physiological basis for autonomous growth of the crown-gall tumor cell. Proceedings of the National Academy of Sciences, Washington, v.44, p.44- 349, 1958

5.Braun, A. C.; Mandle, R. J. Studies on the inactivation of the tumor-inducing principie in crown gall. Growth, Lakeland, v.12, p.255- 269, 1948

6.Campbell, A. M.; Tok, J. B.; Zhang, J.; Wang, Y.; Stein, M.; Lynn, D. G.; Binns, A. N. Xenognosin sensing in virulence: Is there a phenol receptor in Agrobacterium tumefaciens? Chemistry and Biology, Cambridge, v.7, p.65-76, 2000.

7.Charles, T. C., Jin, S.; Nester, E. W. Two-component sensory transduction systems in phytobacteria. Annual Review of Phytopathology, Palo Alto, v.30, p.463-484, 1992

8.Chilton, M. D. A vector for introducing new genes into plants Agrobacterium tumefaciens, genetic engineering. Scientific American, New York, v.248, p.50-59, 1983

9.Chilton, M. D. Agrobacterium. A memoir. Plant Physiology, Rockville, v.125, p.9-14, 2001

10.Chilton, M. D.; Drummond, M. H.; Merio, D. J.; Sciaky, D.; Montoya, A. L.; Gordon, M. P.; Nester, E. W. Stable incorporation of plasmid DNA into higher plant cells: the molecular basis of crown gall tumorogenesis. Cell, Cambridge, v.11, p.263-271, 1977

11.Darnell, J., Lodish, H.; Baltimore, D. Molecular cell biology, 2nd ed. New York, Scientific American Books, 1990, 1105p

12.Escobar, M. A.; Dandekar, A. M. Agrobacterium tumefaciensas an agent of disease. Trends in Plant Science, London, v.8, p.380386,2003

13.Gelvin, S. B. Agrobacterium and plant genes involved in T-DNA transfer and integration. Annual Review of Plant Physiology and Plant Molecular Biology, Palo Alto, v.51, p.223-256, 2000

14.Gerhardt, P. E. Methods for general and molecular bacteriology. Washington, American Society for Microbiology. 1994. 791p

15.Hess, K. M.; Dudley, M. W.; Lynn, D. G.; Joerger, R. D.; Binns, A. N. Mechanism of phenolic activation of Agrobacterium virulence genes: development of a specific inhibitor of bacterial sensor/ response systems. Proceedings of the National Academy Science, Washington, v.88, p.7854-7858, 1991

16.Hooykaas, P. J. J.; Beijersbergen, A. G. M. The virulence system of Agrobacterium tumefaciens. Annual Review of Phytopathology, Palo Alto, v.32, p.157-179, 1994

17.Jia, Y. H.; Li, L. P.; Hou, Q. M.; Pan, S. Q. An Agrobacterium gene involved in tumorigenesis encodes an outer membrane protein exposed on the bacterial cell surface. Gene, Orlando-Amsterdam, v.284, p.113-124, 2002

18.Joubert, P.; Beaupere, D.; Lelievre, P.; Wadouachi, A.; Sangwan, R. S.; Sangwan, N. B. S. Effects of phenolic compounds on Agrobacterium vir genes and gene transfer induction: A plausible molecular mechanism of phenol binding protein activation. Plant Science, Orlando-Amsterdam, v.162, p.733-743, 2002

19.Kado, C. I. The role of the T-pilus in horizontal gene transfer and tumorigenesis. Current Opinion in Microbiology, Oxford, v.3, p.643-648, 2000

20.Kelly, B. A.; Kado, C. I. Agrobacterium-mediated T-DNA transfer and integration into the chromosome of Streptomyces lividans. Molecular Plant Pathology, Oxford, v.3, p.125-134, 2002

21.Kerr, A. Transfer of virulence between isolates of Agrobacterium. Nature Biotechnology, New York, v.223, p.1175-1176, 1969

22.Kim, K.; Farrand, S. K.; Kim, K. S. Ti plasmid-encoded genes responsible for catabolism of the crown gall opine mannopine by
Agrobacterium tumefaciensare homologs of the T-region genes responsible for synthesis of this opine by the plant tumor. Journal of Bacteriology, Birmingham, v.178, p.3275-3284, 1996

23.Kiraly, Z.; Klement, A.; Solimosy, F.; Voros, J. Methods in plant pathology. Budapest:Akademiai Kiadó. 1970, 509p

24.Lee, Y.; Jin, S.; Sim, W.; Nester, E. W.; Lee, Y. W.; Jin, S. G.; Sim, W. S. Genetic evidence for direct sensing of phenolic compounds by the VirA protein of Agrobacterium tumefaciens. Proceedings of the National Academy of Sciences of the United States of America, Washington, v.92, p.12245-12249, 1995

25.Li, L.; Jia, Y.; Hou, Q.; Charles, T. C.; Nester, E. W.; Pan, S. Q. A global pH sensor: Agrobacterium sensor protein ChvG regulates acid-inducible genes on its two chromosomes and Ti plasmid. Proceedings of the National Academy of Sciences of the United States of America, Washington, v.99, p.12369-12374, 2002

26.Link, G. K.; Eggers, V. Hyperauxiny in crown gall of tomato. Botanical Gazette, Chicago, v.103, p.87-106, 1941

27.Lippincott, J. A.; Lippincott, B. B. The genus Agrobacterium and plant tumorogenesis. Annual Review of Microbiology, Palo Alto, v.29, p.377-405, 1975

28.Llosa, M.; Zupan, J.; Baron, C.; Zambryski, P. The N- and Cterminal portions of the Agrobacterium VirB1 protein independently enhance tumorigenesis. Journal of Bacteriology, Birmingham, v.182, p.3437-3445, 2000

29.Madigan, M. M.; Martinko, J.; Parker, J. E. Brock biology of microorganisms, 10th ed. New York: Prentice Hall, 2003, $1104 \mathrm{p}$

30.Nester, E. W. DNA and protein transfer from bacteria to eukaryotes - the Agrobacterium story. Molecular Plant Pathology, Oxford, v.1, p.87-90, 2000

31.Peng, W. T.; Lee, Y. W.; Nester, E. W. The phenolic recognition profiles of the Agrobacterium tumefaciens VirA protein are broadened by a high level of the sugar binding protein ChvE. Journal of Bacteriology, Birmingham, v.180, p.5632-5638, 1998

32.Petit, A.; Delhaye, S.; Tempé, J.; Morel, G. Recherches sur les guanidines des tissus de crown gall. Mise en évidence d'une relation biochemique spécifique entre les souches d'Agrobacterium tumefaciens et les tumeurs quelles induisent. Physiologie Vegetale, Paris, v.8, p.205-213, 1970

33.Romantschuk, M.; Roine, E.; Taira, S. Hrp pilus: Reaching through the plant cell wall. European Journal of Plant Pathology, Dublin, v.107, p.153-160, 2001

34.Romeiro, R. S. Bioquímica da interação bactéria-planta. Viçosa: UFV, 1985. 29p

35.Schrammeijer, B., den, D. R. A., Vergunst, A. C., Jacome, E. J. \& Hooykaas, P. J. J. Analysis of Vir protein translocation from Agrobacterium tumefaciens using Saccharomyces cerevisiae as a model: Evidence for transport of a novel effector protein VirE3. Nucleic Acids Research, Oxford, v.31, p.860-868, 2003

36.Shimoda, N.; Toyoda Yamamoto, A.; Nagamine, J.; Usami, S.; Katayama, M.; Sakagami, Y.; Machida, Y. Control of expression of Agrobacterium vir genes by synergistic actions of phenolic signal molecules and monosaccharides. Proceedings of the National Academy of Sciences of the United States of America, Washington, v.87, p.6684-6688, 1990

37.Smith, E. F.; Townsend, C. O. A plant tumor of bacterial origin. Science, Washington, v.25, p.671-673, 1907

38.Stanier, R. Y.; Ingraham, J. L.; Wheelis, M. L.; Painter, P. R. The microbial world, 5nd ed. New Jersey: Prentice Hall, 1986. 689p

39.Stapp, C. Bacterial plant pathogens. Oxford: University Press, 1961. $292 \mathrm{p}$

40.Veena, J. H.; Doerge, R. W.; Gelvin, S. B. Transfer of T-DNA and Vir proteins to plant cells by Agrobacterium tumefaciens induces expression of host genes involved in mediating transformation \& suppresses host defense gene expression. Plant Journal, Oxford, v.35, p.219236, 2003

41.Ward, D. V. W.; Zambryski, P. C. The six fuctions of Agrobacterium VirE2. Proceedings of the National Academy of Sciences, Washington, v.98, p.385-386, 2001

42. White, P. R.; Braun, A. C. A cancerous neoplasm of plants: autono- 
mous bacteria-free crown gall tissue. Cancer Research, Baltimore, v.2, p.597-617, 1942

43.Winans, S. C., Mantis, N. J., Chen, C. Y., Chang, C. H. \& Han, D. C. (1994). Host recognition by the VirA, VirG two-component regulatory proteins of Agrobacterium tumefaciens. Research in Microbiology, Vancouver, v.145, p.461-473, 1994

44.Xu, X. Q.; Pan, S. Q. An Agrobacterium catalase is a virulence factor involved in tumorigenesis. Molecular Microbiology, Pertch, v.35, p.407-414, 2000

45.Zupan, J.; Muth, T. R.; Draper, O.; Zambryski, P. The transfer of DNA from Agrobacterium tumefaciens into plants: A feast of fundamental insights. Plant Journal, Oxford, v.23, p.11-28, 2000 . 